\title{
COMPAIXÃO E PIEDADE: DIFERENTES MODOS DE INTERAÇÃO AFETIVA
}

\section{COMPASSION AND PITY: DIFFERENT MODES OF AFFECTIVE INTERACTION}

ELIANE SOARES DE LIMA*

RESUMO: Partindo de uma análise de base lexical, orientada pelos parâmetros teórico-metodológicos da semiótica de linha francesa, em sua interpretação tensiva, a intenção deste artigo é a de examinar os pontos de semelhança, mas sobretudo os de divergência, na emergência do sentimento de compaixão ou piedade. Para isso, iniciaremos com uma investigação pautada pelas definições dicionarizadas de diferentes línguas neolatinas, para delas depreender os semas constituintes de cada um desses núcleos passionais, bem como os elementos do seu processo de configuração discursiva. Interessa, ao desdobrar a estrutura sintáxica subjacente a cada um dos lexemas-afetos, compreender o que, a partir de uma mesma cena predicativa, determina dois modos de interação afetiva distintos: um mais sensível, próprio a um "sentir com", outro mais inteligível, típico de um "sentir por".

* Docente da UNIFRAN - Universidade de Franca. E-mail: eliane.lima@unifran.edu.br . 
PALAVRAS-CHAVE: Semiótica. Paixões. Compaixão. Piedade. Interação passional.

ABSTRACT: From a lexical-based analysis, guided by the theoretical-methodological parameters of French Semiotics in its tensive approach, the aim of this article is to examine the points of similarity and, above all, the divergent ones in the production of the feeling of compassion or pity. In doing so, we will start with an investigation based on the dictionary entries of different Romance languages in order to infer the semes that constitute each passionate nucleus, as well as the elements of the process of discourse configuration. By unfolding the syntax structure underlying every lexemeaffection, our interest relies on understanding what determines two modes of different affective interactions - a more sensitive one, which pertains to a "feeling with", and a more intelligible one, typical of a "feeling for" - through the same predicative scene.

KEYWORDS: Semiotics. Passions. Compassion. Pity. Affective interaction.

\section{0 estudo das paixões em semiótica}

As paixões, do ponto de vista da semiótica francesa, interessam enquanto efeitos de sentido derivados de determinada situação de interação, apresentando-se como configurações discursivas passíveis de ser descritas por meio de propriedades sintáxicas. De um lado, elas procedem das modulações do estado do sujeito na sua relação com um objeto-valor, ou seja, com os valores investidos no objeto e que o tornam desejável, 
detestável, temível etc. De outro, provêm da estrutura modal a partir daí instituída, definidora do "ser" do sujeito apaixonado e da inter-relação que ele estabelece com tal objeto-valor. A passionalidade nasce, dessa forma, diretamente da ligação do sujeito com o objeto, ou, mais especificamente, com o valor que ele representa; o que explica a ideia inicial da teoria de que "para explicar as paixões, é preciso recorrer às relações actanciais, aos programas e percursos narrativos" (BARROS, 2001, p. 62).

Foi pensando assim que, nos primeiros desenvolvimentos da semiótica das paixões, privilegiou-se a análise lexical, procurando examinar as paixões-lexema (cólera, avareza, ciúme etc.) e suas expressões discursivas a partir de uma lógica sintagmática suscetível de explicitar o processo estrutural subjacente às definições. Tratava-se do estudo de interações passionais já fixadas pelo uso em determinada cultura, as quais, além do modo próprio de convocação do sensível e do inteligível, tinham também pré-estabelecida, enquanto configurações canônicas, uma estrutura actancial e narrativa, isto é, um conjunto de funções, ou de "signos passionais", que permitiam a sua identificação, o seu reconhecimento. É por isso que, segundo Greimas (1983), os lexemas se apresentam como condensações de estruturas discursivas e narrativas, contendo as primeiras informações sobre a maneira como "funcionam" as paixões. Ele explica (1983, p. 251): “as descrições lexemáticas podem constituir, de modo econômico, modelos de previsibilidade para análises discursivas posteriores".

Cientes do relativismo cultural ligado ao léxico, uma vez que cada língua utiliza formas variadas e específicas para conceituar comportamentos patêmicos de mesma natureza, optamos por iniciar a investigação acerca dos efeitos de sentido passionais de compaixão e piedade também com um exame 
de base lexical em diferentes línguas neolatinas (português, francês, italiano e espanhol). Acreditamos que, mesmo mantendo relações semânticas de vizinhança e de imbricação, essas duas paixões possuem particularidades sintáxicas específicas, e podem, por isso, ser concebidas como afetos distintos. A significação dicionarizada dessas paixões-lexema, nas línguas consultadas, nos interessa, então, como ponto de apoio para a identificação, avaliação e compreensão das características propriamente formais dos fenômenos significantes que elas nomeiam, com o intuito não de realizar uma investigação puramente semântica, mas de identificar, por meio dos dados levantados pelos semas, os dispositivos e as operações gerais presentes na produção dos dois núcleos patêmicos em pauta - segundo sua concepção na cultura ocidental -, averiguando, além disso, pelo conjunto da organização estrutural latente às definições, as semelhanças e as diferenças de um afeto e outro, bem como a relevância do componente tensivo-fórico para o estudo das paixões na perspectiva da semiótica discursiva.

Assim, percorreremos, a princípio, as definições de compaixão e piedade encontradas em alguns dos dicionários das principais línguas neolatinas, o português, o francês, o italiano e o espanhol, isso porque nossa intenção é a de depreender, por meio desta consulta variada, as peculiaridades da cena predicativa que faz emergir a afetividade em questão, para, em seguida, poder chegar a uma (re)formulação sintáxica do conteúdo semântico de compaixão e piedade. 0 intuito é o de transformar, como fazia Greimas (1983, 1993, 2002), os "nomes-lexema" em "patemas-processo", identificando, a partir daí, tanto as organizações modais subjacentes, quanto as operações tensivas que as predispõem a participar de configurações passionais ora mais sensíveis ora mais inteligíveis.

A investigação das acepções nas diferentes línguas em 
pauta se justifica pelo nosso interesse de poder delinear uma visão mais abrangente, propícia à comparação das definições registradas para as duas paixões-lexemas. Esperamos com isso poder depreender as condições de emergência da interação afetiva estabelecida em um estado de alma e outro, verificando as peculiaridades próprias à manifestação discursiva de um e outro efeito passional.

\section{Entre compaixão e piedade: diferentes tipos de pesar pelo outro}

Tanto compaixão quanto piedade, independente das interpretações axiológicas que recebam nas diferentes culturas, remetem, de maneira geral, ao pesar provocado quando se testemunha o sofrimento de um ser vivo. Todavia, conforme assinala Ricot (2013, p. 91¹), "é rude a concorrência lexical para exprimir o sentimento experimentado diante da infelicidade de outrem". Entre compaixão e piedade, há pena, dó, comiseração, lástima, condoimento, caridade, enternecimento, pesar, simpatia etc., "como se esta multiplicação terminológica fosse o indício de uma busca desesperada por uma palavra enfim apropriada, uma ideia adequada, difícil de estabelecer em razão dos impasses encontrados em torno da própria noção e de seu papel na vida moral" (RICOT, p. 92²).

As acepções encontradas para esses lexemas em grande parte dos dicionários de língua portuguesa, por exemplo, não

1 Trecho original: "La concurrence lexicale est rude pour exprimer le sentiment éprouvé devant le malheur d'autrui."

2 Trecho original: “Comme si cette multiplication terminologique était l'indice d'une recherche désespérée, grâce à un mot enfin approprié, d'une idée adéquate, difficile à établir en raison des écueils rencontrés autour de la notion elle-même et de son rôle dans la vie morale." 
dizem muito, na maioria das vezes, a respeito da nuance entre o significado de cada um deles, colocando-os, ao contrário, como se pode observar abaixo (Quadro 1), uns como sinônimos dos outros.

Quadro 1 - Quadro comparativo do léxico em língua portuguesa relacionado ao campo semântico de compaixão e piedade.

\begin{tabular}{|c|c|}
\hline \multicolumn{2}{|c|}{ CAMPO LEXICAL NO QUAL SE INSCREVEM COMPAIXÃO E PIEDADE } \\
\hline \multicolumn{2}{|r|}{ Acepções dicionarizadas } \\
\hline amerceamento & $\begin{array}{l}\text { s.m. } 1 \text { ato ou efeito de amercear(-se); amerceadura, } \\
\text { compaixão; } 2 \text { remissão total ou parcial da culpa. } \\
\text { *amercear(-se): v.t.d.p.1 conceder mercê a; } \\
\text { compadecer-se, apiedar-se; [...] }\end{array}$ \\
\hline caridade & $\begin{array}{c}\text { s.f. [...] } 2 \text { Derivação: por metonímia. ato pelo qual se } \\
\text { beneficia o próximo, esp. os pobres e os desprotegidos; } \\
3 \text { disposição favorável em relação a alguém em } \\
\text { situação de inferioridade (física, moral, social etc.); } \\
\text { compaixão, benevolência, piedade; [...] }\end{array}$ \\
\hline comiseração & $\begin{array}{l}\text { s.f. sentimento de piedade pela infelicidade de outrem; } \\
\text { compaixão, miseração. }\end{array}$ \\
\hline compadecimento & $\begin{array}{l}\text { s.m. } 1 \text { ato ou efeito de compadecer(-se); compaixão; } \\
1.1 \text { condescendência, benevolência. } \\
\text { *compadecer(-se): v.t.d.p. } 1 \text { sentir compaixão (de), } \\
\text { condoer-se (de). [...] }\end{array}$ \\
\hline compungimento & $\begin{array}{l}\text { *compungir(-se): v.t.d.p. [...] } 2 \text { causar a, ou sentir } \\
\text { enternecimento; } \\
\text { sensibilizar(-se). }\end{array}$ \\
\hline condoimento & $\begin{array}{l}\text { s.m. sentimento ou estado de quem se condói; } \\
\text { compaixão, condolência, pena. }\end{array}$ \\
\hline
\end{tabular}




\begin{tabular}{|c|c|}
\hline condolência & $\begin{array}{l}\text { s.f. } 1 \text { estado de quem se condói; sentimento de pesar; } \\
\text { compaixão, pena. [...] }\end{array}$ \\
\hline dó & $\begin{array}{c}\text { s.m..1 sentimento de pena com relação a alguém, a si } \\
\text { mesmo ou a alguma coisa; compaixão; } 2 \text { expressão } \\
\text { de grande tristeza e mágoa por alguém, por si ou por } \\
\text { alguma coisa; pesar. [...] }\end{array}$ \\
\hline enternecimento & $\begin{array}{c}\text { s.m. }[\ldots] 2 \text { sentimento de pena com relação a alguém, a } \\
\text { si mesmo ou a coisa; compaixão, dó. }\end{array}$ \\
\hline lástima & $\begin{array}{l}\text { s.f. ato ou efeito de lastimar(-se); } 1 \text { sentimento de pena; } \\
\text { compaixão, dó; } 2 \text { Derivação: por metonímia. Aquilo que } \\
\text { merece ser lastimado; mal; } 3 \text { lamentação interminável; } \\
\text { queixa, lamúria; } 4 \text { revés da fortuna; desgraça, desdita, } \\
\text { infortúnio. }\end{array}$ \\
\hline misericórdia & $\begin{array}{l}\text { s.f. } 1 \text { sentimento de dor e solidariedade com relação a } \\
\text { alguém que } \\
\text { sofre uma tragédia pessoal ou que caiu em desgraça; } \\
\text { dó, compaixão, } \\
\text { piedade; } 2 \text { ato concreto de manifestação desse } \\
\text { sentimento, } \\
\text { como o perdão; indulgência, graça, clemência. [...] }\end{array}$ \\
\hline pena & $\begin{array}{l}\text { s.f. } 2 \text { sofrimento; aflição; } 3 \text { compaixão, piedade, } \\
\text { comiseração; } \\
4 \text { tristeza, amargura, pesar. [...] }\end{array}$ \\
\hline pesar & [...] s.m.12 sentimento de tristeza, de desolação. \\
\hline simpatia & $\begin{array}{l}\text { s.f. } 1 \text { afinidade moral, similitude no sentir e no pensar } \\
\text { que aproxima } \\
\text { duas ou mais pessoas; [...] } 5 \text { faculdade de } \\
\text { compenetrar-se das ideias ou sentimentos de outrem; } \\
{[\ldots]}\end{array}$ \\
\hline \multicolumn{2}{|c|}{$\begin{array}{l}\text { Fonte: Dicionário Houaiss da Língua Portuguesa. 1.ed. Rio de Janeiro: Objetiva; } \\
\qquad 2009^{3} .\end{array}$} \\
\hline
\end{tabular}

Fonte: Elaboração própria.

3 Embora só as definições do Dicionário Houaiss da língua portuguesa tenham sido aqui elencadas, a consulta estendeu-se a vários outros dicionários de português. A opção pela apresentação de um único, como representante da língua de um modo geral, deve-se à falta de distinção significativa entre as acepções encontradas 
Mesmo as definições de compaixão e piedade propriamente ditas, embora chamem, em alguns casos, a atenção para certa distinção entre as acepções, frequentemente, cruzam os conteúdos, apresentando-as como paixões equivalentes (Quadro 2).

Quadro 2: Quadro comparativo das definições de compaixão e piedade encontradas em dicionários de língua portuguesa.

\begin{tabular}{|c|c|}
\hline COMPAIXÃO & PIEDADE \\
\hline \multicolumn{2}{|c|}{ Acepções dicionarizadas } \\
\hline $\begin{array}{c}\text { s.f. sentimento que nos desperta a } \\
\text { desgraça; pesar que nos desperta } \\
\text { o mal alheio, dó; comiseração; o } \\
\text { estado daqueles infelizes causa } \\
\text { compaixão; [...] }\end{array}$ & $\begin{array}{l}\text { s.f. Devoção, amor e respeito } \\
\text { pelas coisas religiosas; religião, } \\
\text { devoção. // Respeito pelos mortos. } \\
\text { // Sentimento inspirado pelos males } \\
\text { alheios e que se dispõe a remediá- } \\
\text { los ou a mitigá-los. // Compaixão; } \\
\text { dó; comiseração. [...] }\end{array}$ \\
\hline \multicolumn{2}{|c|}{$\begin{array}{l}\text { Fonte: Dicionário contemporâneo da Língua Portuguesa, vol. 4, Caldas Aulete, } \\
\qquad 4^{a} \text { ed., Rio de Janeiro: Delta, } 1958 .\end{array}$} \\
\hline $\begin{array}{l}\text { s.f. Pesar que em nós desperta a } \\
\text { infelicidade, a dor, o mal de outrem; } \\
\text { piedade, pena, dó, condolência. }\end{array}$ & $\begin{array}{l}\text { s.f. } 1 \text { Amor e respeito às coisas } \\
\text { religiosas; religiosidade; devoção. } \\
2 \text { Pena dos males alheios; } \\
\text { compaixão, dó, comiseração; [...] }\end{array}$ \\
\hline \multicolumn{2}{|c|}{$\begin{array}{l}\text { Fonte: Novo Aurélio Século XXI: o dicionário da língua portuguesa, } 3^{\mathrm{a}} \text { ed., Rio de } \\
\text { Janeiro: Nova Fronteira, } 1999 .\end{array}$} \\
\hline
\end{tabular}




\begin{tabular}{|c|c|}
\hline $\begin{array}{l}\text { s.f. sentimento piedoso de simpatia } \\
\text { para com a tragédia pessoal de } \\
\text { outrem, acompanhado do desejo } \\
\text { de minorá-la; participação espiritual } \\
\text { na infelicidade alheia que suscita } \\
\text { um impulso altruísta de ternura para } \\
\text { com o sofredor. }\end{array}$ & $\begin{array}{l}\text { s.f. } 1 \text { devoção, amor pelas coisas } \\
\text { religiosas; religiosidade; } 1.1 \\
\text { Rubrica: religião; virtude que } \\
\text { permite render a Deus o culto que } \\
\text { Ihe é devido; } 2 \text { compaixão pelo } \\
\text { sofrimento alheio; comiseração, dó, } \\
\text { misericórdia. }\end{array}$ \\
\hline \multicolumn{2}{|c|}{$\begin{array}{l}\text { Fonte: Dicionário Houaiss da Língua Portuguesa. 1.ed. Rio de Janeiro: Objetiva; } \\
\qquad 2009 .\end{array}$} \\
\hline $\begin{array}{c}\text { s.f. 1. Sentimento benévolo que } \\
\text { nos inspira a infelicidade ou o mal } \\
\text { alheio. } \\
\text { 2. Dó; lástima; piedade. }\end{array}$ & $\begin{array}{l}\text { 1. Prática das leis religiosas. = } \\
\text { DEVOÇÃO } \\
\text { 2. Vontade de diminuir ou se } \\
\text { solidarizar com o sofrimento alheio. } \\
\text { = COMPAIXÃO, DÓ, LÁSTIMA, } \\
\text { MISERICÓRDIA }\end{array}$ \\
\hline \multicolumn{2}{|c|}{$\begin{array}{l}\text { Fonte: Dicionário Priberam da Língua Portuguesa [em linha], 2008-2013, http:// } \\
\text { www.priberam.pt/DLPO/piedade (consultado em 28-11-2013). }\end{array}$} \\
\hline
\end{tabular}

Fonte: Elaboração própria.

Embora haja uma remissão à religiosidade, a certo "dever religioso", no caso da piedade, que não aparece na definição de compaixão, essas duas paixões "nucleares", se assim podemos dizer, são claramente concebidas como sendo sinônimas. Na designação de compaixão aparece o termo "sentimento piedoso", "piedade", e, do mesmo modo, na de piedade há sempre a referência à compaixão. Com os termos "periféricos" (pena, dó, comiseração etc.) o mesmo se verifica, e o que temos é na, maioria das vezes, um grupo de palavras consideradas parassinônimas, que remetem umas às outras sem maior detalhamento da nuance existente entre as interações afetivas distintamente nomeadas.

Se pensarmos, por outro lado, na práxis enunciativa envolvida no uso dessas paixões-lexema, a relação de sinonímia entre 
elas parece se diluir um pouco, e um termo é quase sempre preferido em vista dos outros, a depender da situação e da conotação que queremos afirmar ou negar. Isso porque, mesmo com as definições dicionarizadas não salientando a diferença entre uma paixão e outra, sabemos que o sentimento de pesar pelo padecimento de outrem pode se apresentar tanto de forma natural, irrefletida - quando há mesmo um movimento de partilha da dor daquele que sofre, um "sentir com" -, quanto como resultado de uma avaliação menos espontânea, mais cognitiva, a partir da qual o observador, ao assumir uma perspectiva exterior e objetiva, compara a sua situação positiva àquela disfórica do sofredor, sensibilizando-se mediante um "sentir por", que põe em cena não a comunhão de sentimentos, mas uma relação de alteridade entre um e outro, entre aquele que testemunha o padecimento e aquele que o vive. Como assinala Rousseau (2004, p. 310), “a piedade é doce, porque, ao nos colocarmos no lugar daquele que sofre, sentimos contudo o prazer de não sofrer com ele".

De acordo com Ricot (2013, p. 104), “a língua hesita hoje em usar a palavra piedade porque o termo acabou adquirindo no uso uma significação de condescendência, e mesmo de desprezo e desdém, que parece não ter contaminado tão fortemente o de compaixão". De fato, nos dicionários de referência da língua francesa (Quadro 3), as definições de compaixão e piedade apontam mais claramente para essa diferença de configuração da identificação entre os sujeitos em cada um dos casos. Mesmo concebidas como estados de alma sinônimos, na acepção de compaixão aparece o sema da partilha; o que não acontece no caso da piedade, quando se faz inclusive menção a certo desprezo.

4 Trecho original: “[...] la langue hésite aujourd'hui à employer le mot de pitié parce que le terme a pris, assez souvent dans l'usage, une signification de condescendance, voire de mépris et de dédain, qui semble avoir moins contaminé celui de compassion." 
Quadro 3: Quadro comparativo das definições encontradas em dicionários de língua francesa.

\begin{tabular}{|c|c|}
\hline COMPASSION (Compaixão) & PITIÉ (Piedade) \\
\hline \multicolumn{2}{|c|}{ Acepções encontradas em dicionários de língua francesa } \\
\hline $\begin{array}{l}\text { nf Sentiment qui nous fait compatir. } \\
2 \text { État de celui qui est à plaindre. } \\
\text { sf Sentimento que nos faz sofrer com } \\
\text { o outro. } \\
2 \text { Estado daquele por quem se } \\
\text { lamenta. }\end{array}$ & $\begin{array}{l}\text { nf } 1 \text { Sentiment qui saisit à la vue } \\
\text { des souffrances et qui porte à les } \\
\text { soulager. } 2 \text { Pitié, se dit quelquefois } \\
\text { en un sens où il entre quelque } \\
\text { mépris. } \\
\text { sf } 1 \text { Sentimento que nos toma ante } \\
\text { os sofrimentos de outrem e que nos } \\
\text { inclina a aliviá-los. } 2 \text { Piedade, diz-se } \\
\text { algumas vezes com algum desprezo }\end{array}$ \\
\hline \multicolumn{2}{|c|}{$\begin{array}{l}\text { Fonte: Dictionnaire de français Littré (en ligne). } \\
\text { Disponível em: http://littre.reverso.net/dictionnaire-francais/definition/ } \\
\text { compassion }\end{array}$} \\
\hline $\begin{array}{l}\text { Littér. Sentiment qui porte à plaindre } \\
\text { et partager les maux d'autrui. }\end{array}$ & $\begin{array}{c}1 \text { Sympathie qui naît de la } \\
\text { connaissance des souffrances } \\
\text { d'autrui et fait souhaiter qu'elles } \\
\text { soient soulagées. } 2 \text { Sentiment } \\
\text { de commisération accompagné } \\
\text { d'appréciation défavorable ou de } \\
\text { mépris. }\end{array}$ \\
\hline $\begin{array}{l}\text { Literal. Sentimento que nos compele } \\
\text { a ter pena dos males alheios e a } \\
\text { compartilhá-los. }\end{array}$ & $\begin{array}{c}1 \text { Simpatia que nasce a partir do } \\
\text { reconhecimento dos sofrimentos } \\
\text { alheios e que nos faz desejar que } \\
\text { eles sejam aliviados. } 2 \text { Sentimento } \\
\text { de comiseração acompanhado } \\
\text { de apreciação desfavorável ou de } \\
\text { desprezo. }\end{array}$ \\
\hline \multicolumn{2}{|c|}{ Fonte: Dictionnaire Le Petit Robert de la langue française. CD-ROM } \\
\hline
\end{tabular}

Fonte: Elaboração própria.

Nos dicionários de língua italiana, por sua vez, embora os 
termos compaixão e piedade também apareçam como sinônimos, com os dois "tipos de pesar" sendo mencionados, ocorre exatamente o contrário, e é a piedade o afeto definido de maneira mais positiva, euforizada, considerada como um sentimento forte, de natureza propriamente patêmica, e não a compaixão, a qual está associada o sema pejorativo do desprezo e do desdém. Mesmo com a presença do sema da "partilha", do "sentir com", o sentimento compassivo é, na maioria das vezes, como se pode observar no quadro comparativo reproduzido abaixo (Quadro 4) ${ }^{5}$, passível de uma apreciação negativa, disforizada.

Quadro 4: Quadro comparativo das definições de compaixão e piedade encontradas em dicionários de língua Italiana.

\begin{tabular}{|c|c|}
\hline COMPASSIONE (Compaixão) & PIETÀ (Piedade) \\
\hline \multicolumn{2}{|c|}{ Acepções encontradas em dicionários de língua italiana } \\
\hline $\begin{array}{l}\text { s.f. } 1 \text { Atteggiamento comprensivo e } \\
\text { soccorrevole di fronte ad uno stato } \\
\text { penoso [...] Situazione o condizione } \\
\text { che induca a assistere altri con la } \\
\text { própria partecipazione affetiva. } 2 \\
\text { Reazione negativa sottolineata da } \\
\text { disprezzo, di fronte alle azione o al } \\
\text { comportamento altrui [...] }\end{array}$ & $\begin{array}{l}\text { s.f. } 1 \text { Sentimento di dolorosa e } \\
\text { premurosa partecipazione alla } \\
\text { infelicità altrui [...] } 2 \text { lett. La riverenza } \\
\text { o la devozione, in quanto riconducibili } \\
\text { all'ambito degli affetti o dei doveri } \\
\text { domestici, sociali, religiosi [...] }\end{array}$ \\
\hline $\begin{array}{l}\text { s.f. } 1 \text { Comportamento compreensivo } \\
\text { e auxiliador diante de um estado } \\
\text { penoso [...] Situação ou condição } \\
\text { que induz a ajudar outras pessoas, } \\
\text { participando afetivamente. } 2 . \\
\text { Reação negativa acentuada pela } \\
\text { indiferença diante de ações ou do } \\
\text { comportamento alheio [...] }\end{array}$ & $\begin{array}{l}\text { s.f. } 1 \text { Sentimento de dolorosa e } \\
\text { atenciosa participação na infelicidade } \\
\text { alheia [...]. 2. (lit.) A reverência ou a } \\
\text { devoção enquanto direcionadas aos } \\
\text { afetos ou aos deveres domésticos, } \\
\text { sociais, religiosos [...] }\end{array}$ \\
\hline $\begin{array}{r}\text { Fonte: DEVOTO, Giacomo; OLI, Gian } \\
\text { Firenze: Le }\end{array}$ & $\begin{array}{l}\text { arlo Dizionario della Lingua Italiana. } \\
\text { nnier, } 1971 .\end{array}$ \\
\hline
\end{tabular}

5 A tradução dos verbetes em italiano foi gentilmente feita por Carolina Tomasi. 


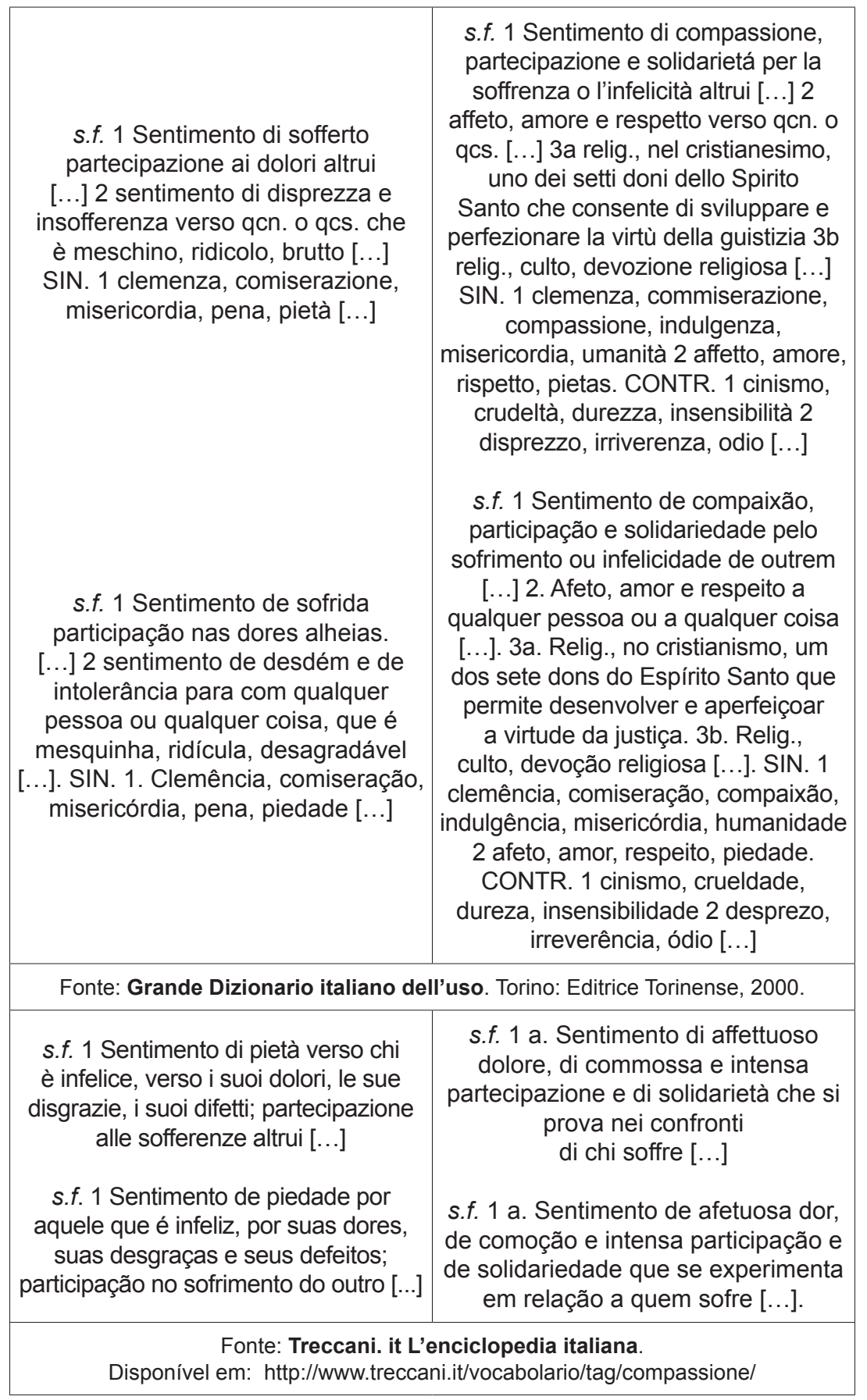

Fonte: Elaboração própria. 
Nos dicionários de espanhol, compaixão e piedade também são consideradas sinônimas, mas a constância do sema da religiosidade na definição desta última (Quadro 5) chama a atenção, apontando para a conotação do "dever" (moral) presente nesse tipo de interação. Diferentemente do que acontece nos outros dicionários examinados, nos quais esse sema pode aparecer explicitado ou não, no contexto espanhol, sua presença é fato consolidado. 0 que, de certa forma, faz subentender, por comparação, uma interpretação sobre a natureza mais espontânea do sentimento de compaixão.

Quadro 5: Quadro comparativo das definições de compaixão e piedade encontradas em dicionários de língua espanhola.

\begin{tabular}{|c|c|}
\hline COMPASIÓN (Compaixão) & PIEDAD (Piedade) \\
\hline \multicolumn{2}{|c|}{ Acepções encontradas em dicionários de língua espanhola } \\
\hline $\begin{array}{l}\text { s/f Sentimiento de lástima por el } \\
\text { mal o desgracia ajenos[...] SIN. } \\
\text { Commiseración, lástima, piedad, } \\
\text { misericordia, caridad. ANT. } \\
\text { Insensibilidad, crueldad. } \\
\text { s/f Sentimento de lástima pelo } \\
\text { mal ou desgraça alheios [...] SIN. } \\
\text { Comiseração, lástima, piedade, } \\
\text { misericórdia, caridade. ANT. } \\
\text { Insensibilidade, crueldade. }\end{array}$ & $\begin{array}{c}\text { s/f } 1 \text { Compasión hacia la persona } \\
\text { que sufre. } 2 \text { Amor a los padres y } \\
\text { a las cosas sagradas. } 3 \text { Celo en } \\
\text { el cumplimiento de los deberes } \\
\text { religiosos. SIN. } 1 \text { Misericordia, } \\
\text { lástima. } 2 \text { Caridad, veneración. } 3 \\
\text { Devoción. } \\
\text { s/f } 1 \text { Compaixão pela pessoa que } \\
\text { sofre. } 2 \text { Amor aos pais e às coisas } \\
\text { sagradas. } 3 \text { Zelo no cumprimento } \\
\text { dos deveres religiosos. SIN. } 1 \\
\text { Misericórdia, lástima. } 2 \text { Caridade, } \\
\text { veneração. } 3 \text { Devoção. }\end{array}$ \\
\hline $\begin{array}{l}\text { Fonte: Gran Diccionario de la leng } \\
\text { General Españ }\end{array}$ & $\begin{array}{l}\text { añola. Alcabendas-Madrid, Sociedad } \\
\text { Libreria, } 1985 .\end{array}$ \\
\hline
\end{tabular}


s/f Lástima, ternura y comprensión que una persona siente hacia outra que sufre o tiene problemas [...] SIN. Misericordia, commiseración, piedad. ANT. Insensibilidad, crueldad.

s/f Lástima, ternura e compreensão que uma pessoa sente por outra que sofre ou tem problemas [...]

SIN. 1 Misericórdia, comiseração, piedade.

ANT. Insensibilidade, crueldade. s/f 1 Sentimiento de compasión por alguien que sufre [...] 2 Sentimiento de religiosidad y dévocion por lo que es o se considera sagrado o digno de veneración [...] SIN. 1 Compasión, clemencia, misericordia.

2 Fervor, devoción.

s/f Sentimento de compaixão por alguém que sofre [...] 2 Sentimento de religiosidade e devoção pelo que é ou se considera sagrado ou digno de veneração [...] SIN. 1 Compaixão, clemência, misericórdia. 2 Fervor, devoção.

Fonte: Gran diccionario de uso del español actual. Alcabendas-Madrid, Sociedad General Española de Libreria, 2001.

f. Sentimiento de commiseración y lástima que se tiene hacia quienes sufren penalidades o desgracias.

$f$. Sentimento de comiseração e lástima que sentimos diante aqueles que sofrem penalidades ou desgraças. $f$. Virtud que inspira, por el amor a Dios, tierna devoción a las cosas santas, y, por el amor al prójimo, actos de amor y compasión. // 2 Amor entrañable que consagramos a los padres y a objetos venerandos.

// 3 Lástima, misericórdia, commiseración [...]

$f$. Virtude que inspira, pelo amor a Deus, terna devoção às coisas santas, e, por amos ao próximo, atos de amor e compaixão. // 2 Grande amor que devotamos aos pais e aos objetos veneráveis. // 3 Lástima, misericórdia, comiseração [...]

Fonte: Diccionario de la Lengua Española. Real Academia Española, 2001, tomo I.

Fonte: Elaboração própria.

Esse breve levantamento das definições de compaixão e piedade nos dicionários das principais línguas neolatinas permite constatar que, mesmo sendo concebidas como paixões sinônimas, de tal forma que as acepções se cruzam e até 
mesmo se confundem, existem, com efeito, duas experiências passionais possíveis subjacentes ao estabelecimento do pesar pelo sofrimento de outrem: uma originária da plena identificação com o outro, própria ao "sentir com", e a outra de uma posição de alteridade em relação a seu padecimento, atrelada ao "sentir por". 0 vestígio, no léxico, dessa assimilação da diferença qualitativa no modo de configuração da interação afetiva instaurada a partir da observação da dor alheia se esclarece, sobretudo, quando examinamos a raiz etimológica dos termos em questão (Quadro 6).

Quadro 6: Quadro comparativo da raiz etimológica de compaixão e piedade.

\begin{tabular}{|c|c|}
\hline COMPAIXÃO & PIEDADE \\
\hline \multicolumn{2}{|c|}{ Etimologia } \\
\hline $\begin{array}{l}\text { lat. compassio,ónis 'comunidade de } \\
\text { sentimentos, sofrimento comum'. }\end{array}$ & $\begin{array}{l}\text { lat. piètas, átis 'cumprimento do } \\
\text { dever, virtude, justiça, fidelidade'. }\end{array}$ \\
\hline \multicolumn{2}{|c|}{$\begin{array}{l}\text { Fonte: Dicionário Houaiss da Língua Portuguesa. 1.ed. Rio de Janeiro: } \\
\text { Objetiva; 2009, (grifo nosso). }\end{array}$} \\
\hline 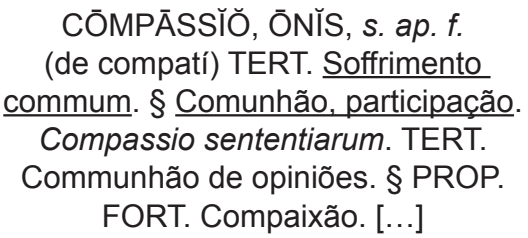 & $\begin{array}{l}\text { Pॉ̌̆TĀS, ĀTIIS, s. ap. f. (de pius) } \\
1^{\circ} \text { Cumprimento do dever, virtude, } \\
\text { justiça, fidelidade, lealdade; } 2^{\circ} \\
\text { Cumprimento dos deveres religiosos, } \\
\frac{\text { sentimento religioso, piedade, culto, }}{\text { devoção; }[. . .]}\end{array}$ \\
\hline $\begin{array}{c}\text { CŌMPĀSSĬBǏLǏS, } \breve{E} \text {, adj. (de } \\
\text { compatí) TERT. Que soffre com, que } \\
\text { partilha o sofrimento. } \S[\ldots]\end{array}$ & 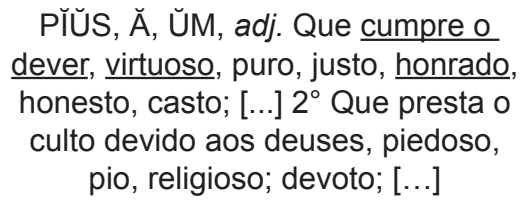 \\
\hline $\begin{array}{l}\text { Fonte: SARAIVA, F. R. dos S. Novíssimo } \\
\text { o plano de L. Quicherat. } 11 \text { ed. Rio de }\end{array}$ & $\begin{array}{l}\text { onário latino-portugês. Redigido segundo } \\
\text { iro: Livraria Garnier, 2000, (grifo nosso). }\end{array}$ \\
\hline
\end{tabular}

Fonte: Elaboração própria. 
A identificação dos dois "tipos de pesar", que de certa forma ainda hoje recobrem, na prática discursiva, o campo semântico de compaixão e piedade, corresponde, como se pode ver, a resquícios da etimologia. 0 sentimento de partilha, de plena identificação com o sofrimento alheio percebido e sentido como sendo próprio diz respeito, a partir desse fundamento etimológico, à compaixão - "compassio, comunidade de sentimentos; sentimento comum”; enquanto o outro, mais próximo a uma obrigação moral, à ideia de conduta esperada, virtuosa, refere-se à piedade - "pietas, cumprimento do dever; virtude; justiça; fidelidade"- cujo grande exemplo literário é Eneias, da Eneida de Virgílio, qualificado pio, embora não haja em sua conduta nenhuma manifestação própria ao sentimento de compaixão.

Nesse sentido, mesmo havendo a frequente "mistura" e "confusão" entre os nomes dados a esses fenômenos passionais, com um tomado pelo outro - piedade como compaixão, ou vice-versa, ou reconhecidos ainda como dó, pena, comiseração, lástima, pesar etc. -, a distinção entre duas formas de lamentar o sofrimento alheio é evidente, o que chama a atenção para a distinção semântica em cada um dos casos. Conforme explica Ricot (2013, p. 136):

Ser tomado de compaixão, compartilhar, "sentir com", da mesma forma que sentir comiseração, é experimentar uma emoção ante a miséria de outrem. Sobre esse aspecto, a compaixão possui uma vantagem inscrita na estrutura de sua etimologia latina, pois ela indica explicitamente a partilha do sofrimento: a relação com o outro, legível diretamente na própria palavra [...].

6 Trecho original: “Être ému de compassion, compatir, 'pâtir avec', de même qu'éprouver de la commisération, c'est ressentir une émotion à la vue de la misère d'autrui. Par ce trait, la compassion possède un avantage inscrit dans la structure de son étymologie latine puisqu'elle indique explicitement la co-souffrance: la relation à l'autre, lisible très directement dans le mot lui-même [...]." 
Ele acrescenta (RICOT, p. 217): “a comiseração é 'um sentimento que nos coloca no lugar daquele que sofre', porque nos comunicamos diretamente com o seu sofrimento. [...] Sofrer 'com' o outro é, portanto, sofrer 'como' o outro". Esse tipo de posicionamento perante a dor de outrem seria, contudo, diferente daquele característico à piedade, quando, conforme assinala o autor (RICOT, p. 21-228):

[...] o padecimento do outro não é o meu. Posso ser afetado pelo seu sofrimento, mas tal sofrimento não é o meu; não sinto o que ele sente, nem imediata, nem diretamente. [...] Identificação não imediata, mas mediada: ela exige uma 'mediação' que traz à cena a irredutível alteridade daquele que é, no entanto, meu semelhante.

Trata-se, portanto, de posicionamentos e modos de interação afetiva diversificados perante o padecimento de outrem, a partir dos quais se pode estabelecer tanto uma identificação fusional, que coloca os interactantes em uma posição de igualdade, de sincronização patêmica, quanto uma identificação com o sofrimento do outro, marcada pela posição de alteridade, na qual se mantém um distanciamento, garantindo ao observador, pelo fato de se encontrar em melhor situação, cer-

7 Trecho original: "La commisération est 'un sentiment qui nous met à la place de celui qui souffre' parce que sa souffrance se communique à nous directement. [...] Pâtir 'avec' autrui serait donc pâtir 'comme' autrui."

8 Trecho original: “[...] la souffrance d'autrui n'est pas la mienne. Je peux être affecté par sa souffrance, mais cette souffrance n'est pas ma souffrance, je n'éprouve pas immédiatement et directement ce qu'il éprouve [...] Identification non pas immédiate mais médiate: elle exige une 'médiation' qui tienne compte de l'irréductible altérité de celui qui est pourtant mon semblable." 
ta superioridade. Nas palavras de Fontanille (2005, p. 2419 ${ }^{9}$, "no primeiro caso, o outro é tratado como um semelhante no movimento mesmo de uma identificação-participação; e, no segundo caso, a avaliação é comparativa, e não absoluta [...]".

A compaixão, ao carregar os semas do "comum", da "comunhão", é, dessa forma, um sentimento mais espontâneo, de origem natural e instintiva, uma partilha mesmo do padecimento do outro, um "sentir junto", isto é, um "sentir com". A piedade, por outro lado, ressaltando o dever moral e a religiosidade, a virtude, aponta para o domínio da razão na configuração afetiva, para a determinação social do estado de alma, a obrigação do sentir em relação ao mal vivido pelo outro, e caracteriza a alteridade e a dissimetria intersubjetiva que configura o compadecimento pelo outro, o "sentir por".

De toda forma, é preciso ir além de uma simples interpretação dos semas. É necessário, como salientavam Greimas e Fontanille (1993), estabelecer, a partir dos segmentos definicionais levantados, os elementos do processo de configuração discursiva de tais estados de alma, de modo que o importante agora é compreender quais circunstâncias de estabelecimento da interação patêmica fazem com que a compaixão seja mais ligada ao sentimento de pesar em si, à identificação e à sensibilização passional que suscitam uma interação tônica, um "sentir com", sendo mais da ordem do sensível, enquanto a piedade, a uma avaliação mais objetiva e distanciada da situação de sofrimento alheio, à alteridade e à moralização, ao inteligível, fazendo surgir um "sentir por", com menor interação intersubjetiva.

9 Trecho original: “[...] dans le premier cas, l'autre est traité comme un semblable dans le mouvement même de participation-identification; et, dans le second cas, l'évaluation est comparative, et non absolue [...]". 


\section{A tradução sintáxica da significação: a estrutura subjacente à definição}

O ponto de vista da semiótica das paixões é o da complexidade, ou seja, o da correlação entre dispositivos e dimensões provenientes de diversos níveis de geração do sentido, de maneira que a todo estado passional subjaz uma estrutura sintáxico-narrativa da qual é possível identificar não só os dispositivos modais, encontrados no fulcro da existência semiótica do sujeito apaixonado, mas também, como temos defendido, as condições subjacentes à sua configuração.

Greimas e Fontanille, no exame da avareza (1993, p. 101), explicam que "o estudo dos lexemas passionais exige primeiro a substituição de uma definição à sua denominação, depois uma reformulação sintática da própria definição", esclarecendo: "trata-se, em suma, de transformar papéis patêmicos, cujos 'nomes-lexema' atestam a existência em dado uso, em patemas-processo e de pôr às claras, graças à análise e à catálise conjugadas, as organizações modais subjacentes".

0 primeiro passo da investigação, de acordo com a maneira de analisar dos autores citados, deve ser, por conseguinte, um levantamento dos segmentos definicionais (Quadro 7) que estão na base dos lexemas examinados, por serem eles os detentores das principais características (sintáxicas) do modo de interação afetiva típico à paixão estudada, à cena narrativa em questão. No exame das condições de configuração dos efeitos passionais de compaixão e piedade privilegiaremos, pois, ao defender a distinção entre eles, os semas passíveis de ser depreendidos a partir da raiz etimológica dos lexemas. Temos, então: 
Quadro 7: Descrição dos segmentos definicionais dos termos em análise.

\begin{tabular}{|c|c|}
\hline COMPAIXÃO & PIEDADE \\
\hline $\begin{array}{c}\text { sofrimento comum; comunhão, } \\
\text { participação. }\end{array}$ & $\begin{array}{c}\text { cumprimento do dever; religiosidade, } \\
\text { virtude. }\end{array}$ \\
\hline simetria; identificação. & dissimetria; alteridade. \\
\hline "sentir com" & "sentir por" \\
\hline
\end{tabular}

Fonte: Elaboração própria.

Cientes de que se trata, em ambos os casos, do sentimento-resposta perante o padecimento de outrem, uma primeira constatação a propósito da semelhança do dispositivo actancial pode ser feita: para que o sentimento de compaixão e/ou piedade surja, é preciso haver, independente do investimento figurativo que recebam no nível discursivo, (i) um dano, (ii) um sujeito por ele afetado e (iii) um sujeito que testemunha a cena em questão. Ademais, essa primeira imposição estrutural e actancial nos leva a inferir ainda um ou outro princípio comum entre os dois estados de alma: a relação intersubjetiva entre os sujeitos envolvidos - o sofredor, objeto-valor ao qual a afetividade suscitada é dirigida; e a testemunha do padecimento, o sujeito da percepção -, assentada no componente fiduciário, o crer, que, nesse caso, desencadeia o processo de interação patêmica, o modo de conjunção interactancial. Se- 
gundo Fontanille (2005, p. $\left.241^{10}\right)$ :

Toda esta série comporta dois pressupostos indispensáveis. A saber:

1. Que o outro esteja em uma situação disfórica: o que implica evidentemente uma apreciação de sua situação, no plano tímico e também axiológico; [...].

2. Que o outro seja reconhecido como um semelhante. [...] experimentar compaixão ou piedade é identificar ao menos um traço compartilhado, que faz do outro um semelhante $[\ldots]$.

Em resumo, para que se configure o estado de alma compassivo ou piedoso, dois "mecanismos" devem atuar na instauração da interação (perceptiva): (i) a interpretação da situação disfórica que se apresenta ao sujeito da percepção; e (ii) o movimento de assemelhação, isto é, de identificação com o sujeito que sofre, seja ela uma identificação plena ou parcial. Ainda nas palavras do autor (FONTANILLE, 2005, p. 24111), "esta apreciação pode ser puramente participativa (pôr-se no lugar do outro), uma identificação somática e sensível; mas ela pode também ser avaliativa, e é então que a manifestação do julgamento se torna depreciativa (nela entra 'algo de desprezo')".

O sujeito compassivo ou piedoso, ao ser testemunha do sofrimento alheio, e acreditando partilhar os mesmos valores,

10 Trecho original: "Toute cette série comporte deux présupposés indispensables. À savoir: 1. Que l'autre soit dans une situation dysphorique: cela implique évidemment une appréciation de sa situation, au plan thymique, voire axiologique; [...]. 2. Que l'autre soit reconnu comme un semblable. [...] éprouver de la compassion ou de la pitié, c'est identifier au moins un trait partagé, qui fera de l'autre un semblable [...].

11 Trecho original: "[...] cette appréciation peut être purement participative (se mettre à la place d'autrui), une identification somatique et sensible; mais elle peut aussi être évaluative, et c'est alors que la seule manifestation du jugement devient dépréciative (il y entre 'quelque chose du mépris')." 
compadece-se, em um movimento de conjunção, porque crê-saber o que o outro está sofrendo, o efeito causado pelo mal que o assola. Assim, o crer(-saber), ao estabelecer, na situação de produção de tais efeitos patêmicos, o elo entre o sujeito da percepção e o objeto percebido, apresenta-se como operação juntiva, como o pivô passional de tais interações afetivas. É ele o responsável pelo "despertar" da experiência patêmica, o elemento que, ao marcar um movimento de identificação, de reconhecimento, assinala a competência do sujeito apaixonado para sentir. Conforme explica Greimas (1983, p. 11912), “o re-conhecimento, ao contrário do conhecimento, é uma operação de comparação daquilo que é 'proposto' [...] e daquilo que já se sabe e/ou se crê". Ele acrescenta (1983, p. 11913), 'fica claro que o 'reconhecimento' é, antes de mais nada, o controle da adequação do novo e do desconhecido ao antigo e ao conhecido, e que a verdade ou falsidade da proposição submetida ao julgamento não passa de seu efeito secundário".

Instaura-se, pois, a propriedade formal fundante das cenas passionais em questão: o sujeito apaixonado, seja o compassivo, seja o piedoso, concebe, a partir da manifestação do sofrimento de outrem (o parecer), e da comparação consigo mesmo, a imanência (o ser) do padecimento, fundando o imaginário (o crer-saber) que o competencializa para sentir. Esse fazer interpretativo, como operação fundada no reconhecimento (GREIMAS, 1983), é, portanto, o elemento-chave da estruturação patêmica do efeito de compaixão e piedade; ele é o responsável pela patemização que faz do sujeito da

12 Trecho original: "Or, la re-connaissance, contrairement à la connaissance, est une opération de comparaison de ce qui lui est 'proposé' [...] et de ce qu'il sait/croire déjà."

13 Trecho original: “On voit bien que la 'reconnaissance' est tout d'abord le contrôle de l'adéquation du nouveau et de l'inconnu à l'ancien et au connu, et que la vérité ou la fausseté de la proposition soumise au jugement n'en est que l'effet secondaire." 
percepção um sujeito apaixonado, um sujeito compassivo e/ ou piedoso.

Nas palavras, e no contexto teórico, do filósofo Adam Smith (1999, p. 24-2514), essa interpretação se confirma:

[...] nós só podemos formular uma ideia sobre a maneira pela qual eles são afetados quando concebemos o que nós mesmos sentiríamos na mesma situação. [...] É só pela imaginação que nós podemos idealizar quais são as suas sensações. E esta capacidade nos permite representar aquilo que poderiam ser nossas próprias sensações se estivéssemos em seu lugar. [...] Seus padecimentos, quando eles são, então, despertados em nós, quando os adotamos e os fazemos nossos, começam a nos afetar; [...]

A atividade epistêmica, como ato cognitivo que sensibiliza e patemiza a relação interactancial, está, nesse sentido, no cerne desse tipo de interação afetiva. De toda maneira, se há um princípio estruturador comum a ambos os estados de alma - que pode talvez explicar o fato de os afetos em causa serem considerados como paixões sinônimas -, o "ser do ser", ou melhor dizendo, o "ser do crer" é, em cada um desses modos de interação afetiva, sobredeterminado, como demonstram os segmentos definicionais descritos anteriormente, por diferentes predicados modais: um querer(-ser) próprio ao sujeito compassivo, e um dever(-ser) para o piedoso.

Uma possibilidade de elucidar essa distinção entre os modos de conjunção em questão parece estar nas duas rela-

14 Trecho original: “[...] nous ne pouvons former une idée de la manière dont ils sont affectés qu'en concevant ce que nous devrions nous-mêmes sentir dans la même situation. [...] Ce n'est que par l'imagination que nous pouvons former une conception de ce que sont ses sensations. Et cette faculté ne peut nous y aider d'aucune autre façon qu'en nous représentant ce que pourraient être nos propres sensations si nous étions à sa place. [...] Ses souffrance, quand elles sont ainsi ramenées en nous, quand nous les avons ainsi adoptées et faites nôtres, commencent enfin à nous affecter; [...]" 
ções apontadas por Barros (2001) no trecho a seguir: a juntiva, entre sujeito e objeto; e a de comunicação, de transmissão de valores entre o sujeito (destinatário) e o seu destinador.

O sujeito do estado é o lugar privilegiado da confluência de duas relações: enquanto sujeito, está em conjunção ou em disjunção com o objeto-valor, enquanto destinatário, papel assumido pelo fato de a junção resultar de um fazer comunicativo, relaciona-se com o destinador. 0 sujeito do estado, por conseguinte, mantém laços afetivos ou passionais com o destinador, que o torna sujeito, e com o objeto, a que está relacionado por conjunção ou por disjunção. (p. 62)

Podemos, então, inferir que na compaixão, cuja modalidade dominante parece ser o querer, a interação entre sujeito compassivo e objeto-valor do pesar (sujeito sofredor) se faz de forma quase direta, marcando uma autodestinação, ou seja, uma sincretização dos papéis actanciais de destinador e destinatário na figura do sujeito compassivo; o que explicaria a identificação síncrona própria a uma interação mais sensível, segundo fazem entender os semas levantados a partir da raiz etimológica. Nesse caso, o crer-saber, a operação de comparação, tem natureza tônica e configura uma conjunção realizada - a dor do outro passa a ser a dor do próprio sujeito da percepção.

Já na piedade, que teria o dever como modalidade regente, a relação entre os actantes envolvidos seria pré-determinada pela discretização, na instauração do sujeito piedoso, das funções de destinador e de destinatário (conduta moral e sujeito da percepção, por exemplo). 0 sentir, ou a sensibilização que patemiza a interação piedosa, não surge, dessa forma, do próprio sujeito, mas de uma imposição (social) de comiseração, uma "obrigação", uma "necessidade" - para usar 
a denominação própria ao dever-ser - que lhe é imposta pelo destinador. Trata-se, aqui, não de uma interação tônica e sensível, como acontece na compaixão, mas de uma inter-relação sobretudo social, e por isso mesmo, átona e mais inteligível, desencadeando uma conjunção atualizada.

Como determinante do modo de interação afetiva estabelecido em uma paixão e outra, o crer-saber dos sujeitos compassivo e piedoso aponta, pois, para distintas maneiras de configuração da competência passional, e, consequentemente, do elo interactancial, do modo de conjunção em cada um dos casos. Estabelece-se, assim, um observador sensível e outro social; e a esse propósito Discini (2011) explica: o observador sensível é, de fato, autocentrado axiológica e afetivamente, enquanto o observador social é aquele que se define segundo um posicionamento pré-determinado socialmente. Ademais, sobre essa mesma questão Greimas e Fontanille (1993, p. 170) acrescentam: "o observador social [...] moraliza a manifestação passional para reafirmar um estado de coisas em detrimento de um estado de alma"; bem ao contrário do que faz o observador sensível ao privilegiar não o estado de coisas, mas sim o estado de alma depreensível da manifestação passional observada.

0 vínculo afetivo estabelecido entre os sujeitos (sujeito da percepção e sujeito do padecimento, o objeto-valor do pesar) é caracterizado, portanto, por um fazer interpretativo, um crer-saber, de natureza qualitativa diferente. Como modalidades de base da configuração do sujeito compassivo e do piedoso, o querer e o dever mostram-se atrelados aos modos de existência do crer e, por conseguinte, do próprio sentir, da junção. De acordo com Fontanille e Zilberberg (2001, p. 255), a crença, concebida como competência, pode mesmo tomar duas formas: 
A primeira é uma crença que, do ponto de vista do caráter predicativo, será endógena e, do ponto de vista tensivo, de abertura: é a assunção (o sujeito assume sua competência como uma eficiência sentida como que "do interior" ou, de todo modo, com plena "autonomia"); a segunda é uma crença exógena e, do ponto de vista tensivo, de fechamento: é a adesão (o sujeito adere à sua competência como uma eficiência sentida "do exterior"; estamos então diante da heteronomia").

0 crer-saber da compaixão se coloca, portanto, como um crer-saber-assumido pelo sujeito, o que faz entender o querer-ser que o configura e a partilha mesma do sofrimento; já o da piedade apresenta-se como crer-saber-aderido, justificando o dever-ser e a motivação exógena do pesar, o não-poder-não-ser, determinado pelo destinador social. Nesse sentido, na compaixão, para a qual atua (Quadro 8) o crer-saber-assumido, a presença do objeto-valor (o padecimento percebido) é tônica, o que explica a maior convocação sensível do sujeito e a plenitude da conjunção afetiva configurada, uma interação realizada, com efeito de fusão entre os actantes envolvidos; na piedade, por outro lado, a presença do objeto-valor é (Quadro 8) átona, dada a instauração do crer-saber-aderido, próprio à atualização da interação afetiva, a uma relação interactancial regida sobretudo pelo inteligível, que não chega a ser da ordem da fusão, assinalando apenas uma aproximação entre os sujeitos, uma não-disjunção. 
Quadro 8: Quadro comparativo das propriedades formais de compaixão e piedade.

\begin{tabular}{|c|c|c|}
\hline $\begin{array}{c}\text { Modo de presença do } \\
\text { objeto-valor da } \\
\text { afetividade }\end{array}$ & $\begin{array}{c}\text { maior densidade de } \\
\text { presença do objeto- } \\
\text { valor do pesar }\end{array}$ & $\begin{array}{c}\text { menor densidade de } \\
\text { presença do objeto- } \\
\text { valor do pesar }\end{array}$ \\
\hline $\begin{array}{c}\text { Modo de convocação do } \\
\text { sensível e do inteligível }\end{array}$ & $\begin{array}{c}\text { maior impacto sensível, } \\
\text { men processamento } \\
\text { inteligível }\end{array}$ & $\begin{array}{c}\text { menor impacto } \\
\text { sensível, maior } \\
\text { processamento } \\
\text { inteligível }\end{array}$ \\
\hline $\begin{array}{c}\text { Modo de existência } \\
\text { do pivô passional }\end{array}$ & $\begin{array}{c}\text { crer-saber assumido } \\
\text { (querer) }\end{array}$ & $\begin{array}{c}\text { crer-saber aderido } \\
\text { (dever) }\end{array}$ \\
\hline Modo de junção & $\begin{array}{c}\text { conjunção } \\
\text { (interação afetiva } \\
\text { realizada) }\end{array}$ & $\begin{array}{c}\text { não-disjunção } \\
\text { (interação afetiva } \\
\text { atualizada) }\end{array}$ \\
\hline $\begin{array}{c}\text { Modo de interação } \\
\text { afetiva instaurado }\end{array}$ & fusão & aproximação \\
\hline
\end{tabular}

Fonte: Elaboração própria.

A natureza do sentir "despertado" pelo crer-saber da compaixão se caracteriza, então, por uma intensidade tônica, advinda do campo de (co)presença, que, com o máximo de convocação sensível, une, de fato, por fusão, o sujeito da percepção e o objeto-valor percebido. Já no caso do sentir próprio à piedade, subjaz uma intensidade interactancial átona, que, resultando em um menor impacto sensível, logo, maior assimilação inteligível, delineia uma interação afetiva de aproximação simplesmente.

Além disso, o querer, resultante do crer-saber-assumido e da interação afetiva realizada, é modalidade endotá- 
xica, isto é, liga enunciados que têm sujeitos idênticos ou em sincretismo, corroborando a ideia de uma simetria de lugares: o sujeito compassivo em conjunção com o padecimento do sujeito sofredor, o objeto-valor percebido. 0 dever, por sua vez, relacionado ao crer-saber-aderido, de afetividade atualizada, é modalidade exotáxica, ligando enunciados que têm sujeitos distintos e definindo uma assimetria de lugares, não por disjunção, que implicaria a cisão interactancial, mas por uma não-disjunção, uma aproximação do sujeito piedoso em relação ao objeto-valor do pesar.

Querer e dever, ao se instituir como qualificação e condição próprias ao "ser do ser", ou seja, ao "ser do crer", mostram-se como modalidades dominantes na configuração do "ser do sentir", da natureza do pesar compassivo e/ ou piedoso, determinando a distinção entre o modo como o sujeito interage e se relaciona afetivamente com o objeto-valor percebido, o padecimento alheio, em cada um dos casos. Na compaixão esse modo de interação afetiva, regido por uma lógica volitiva (querer-ser), explica a espontaneidade do compadecimento desencadeado como um "impulso"; na piedade, para a qual domina a lógica alética (dever-ser), o pesar está mais próximo, conforme vimos, a uma necessidade, e por isso mesmo se apresenta como uma "virtude".

Todas essas propriedades sintáxicas destacadas justificam o fato de a compaixão configurar-se como um "sentir com" e a piedade como um "sentir por", mas elas dizem muito pouco a propósito das circunstâncias nas quais o pivô passional, o crer-saber, delineia-se como um crer-saber-assumido ou como crer-saber-aderido. 0 que condiciona a incitação de um em detrimento do outro? 0 que define a interação como sendo da ordem de uma fusão ou de uma aproximação, e não de uma cisão ou de um desprendimento, por exemplo? 
Pensando que "a paixão não é concebível sem o valor: valor investido nos objetos, axiologias descritivas, obviamente, mas, sobretudo, valores modais e aspectuais, controlados pelas valências tensivas" (FONTANILLE; ZILBERBERG, 2001, p. 313), acreditamos que a resposta a essas questões está nas condições de instauração do campo de presença no qual se sustenta a interação perceptiva e o modo de acesso aos valores atualizados, isto é, valores investidos no objeto da afetividade. Saímos, então, do horizonte das modalizações para entrar no das modulações, que antecedem as modalidades e as patemizam; ou, conforme sustentam Fontanille e Zilberberg (2001, p. 234), passamos a uma assimilação da "modalização como modulação dos efeitos intencionais associados ao estabelecimento de uma dêixis perceptiva; como regulação da comunicação interactancial", com as peculiaridades da junção convertidas em determinações tensivas.

A modalização é, dessa forma, remetida ao campo de percepção do sujeito, com os modos de presença do objeto-valor do afeto intimamente relacionados às condições de base na produção do estado de alma, na articulação do sensível com o inteligível; são eles, como veremos, que regulam e gerenciam esta última.

\section{Da modalidade à modulação: os parâmetros tensivos}

Para melhor compreender as peculiaridades sintáxicas que determinam a emergência de uma identidade modal distinta para o sujeito tomado de compaixão ou piedade - o querer-ser e o dever-ser, respectivamente -, daremos continuidade à exploração das circunstâncias de geração do crer- 
-saber-assumido e do crer-saber-aderido, procurando depreender agora as modulações tensivo-fóricas organizadoras do campo de presença, considerado como domínio espaço-temporal no qual se exerce a percepção e consequentemente a interação afetiva (sensível-inteligível) entre o sujeito (que testemunha o sofrimento de outrem) e o objeto-valor da afetividade provocada (o sujeito sofredor).

Tendo como ponto de partida o fato de as primeiras articulações prefiguradoras das modulações que caracterizam o campo de presença serem da ordem da intensidade e da extensidade da atividade perceptiva, buscaremos, de início, determinar o modo de atuação desses dois demarcadores da interação. Isso nos permitirá apreender o estilo tensivo (contensivo, extensivo, retensivo e distensivo) próprio à emergência da interação compassiva ou piedosa, uma vez que, conforme pontuam Fontanille e Zilberberg (2001, p. 307), “o 'estilo tensivo' de uma paixão é um esquema cujo perfil seria diretamente calculável a partir das mudanças no equilíbrio e na direção da correlação entre a intensidade e a extensidade passionais".

Para que a interpretação patemizante, isto é, o julgamento epistêmico do compassivo ou do piedoso tenha lugar, é preciso haver, como vimos, uma co-presença, uma interação antes de mais nada perceptiva entre o sujeito da percepção e o objeto-valor do pesar (o sofredor); e o estabelecimento dessa inter-relação põe em causa dois pressupostos de base: (i) a maneira pela qual surgem os valores que caracterizam a cena instituída no campo perceptivo do sujeito, responsável pela convocação de sua sensibilidade e inteligibilidade, e (ii) o modo como se constitui a partir daí a presença do objeto-valor da afetividade (aquele que sofre).

Iniciaremos essa segunda etapa da análise buscando, 
portanto, identificar as especificidades da profundidade que caracteriza o campo de presença próprio aos estados de alma de compaixão e piedade. Esta noção está sendo entendida aqui, tal como a concebe a perspectiva tensiva, como resultado da tensão estabelecida entre um centro dêitico, o sujeito da percepção, e os seus horizontes, definidos pela intensidade e extensidade da presença instaurada no campo de coexistência. Como lembra Lopes (2006, p. 11, grifo nosso):

A profundidade proposta é medida pelas correlações entre intensidade e extensidade identificáveis nesse campo posicional. Em princípio, quanto mais distante do centro dêitico (maior extensidade), menor a intensidade sensível - sensível significando, no caso, "perceptiva" e "tímica" simultaneamente; quanto mais próximo do centro dêitico (menor extensidade), maior o impacto sensível, logo a intensidade.

Assim, se a compaixão é, como vimos, prescrita por uma interação de maior sensibilidade, na qual o sujeito da percepção e o objeto-valor do pesar chegam, com a instituição do "sentir com", a se fundir, podemos inferir que o campo de presença estabelecido no momento da interação tem profundidade compacta, fazendo com que os valores investidos no objeto da percepção (o sofrimento de outrem) apareçam para o sujeito observador de modo acelerado e tônico, fortalecendo a sincronização sensível, mas inibindo o tempo de processamento inteligível da presença; ao passo que na piedade, cujos interactantes mantêm-se em relação assimétrica, sem grande convocação estésica, o espaço de co-presença terá, por sua vez, maior profundidade, permitindo aos valores uma emersão um pouco menos acelerada no campo de presença e com menor tonicidade, o que enfraquece, por conseguinte, a convocação sensível, e favorece, por outro lado, a possibili- 
dade de maior assimilação inteligível da presença. Conforme explicam Fontanille e Zilberberg (2001, p. 148):

Se o emissor for tônico, sua ação aparecerá como um golpe, e produzirá no receptor um "efeito"; se o emissor for átono, sua ação aparecerá apenas como "eficiência", e o receptor contentar-se-á em senti-la como "presença". Para o observador, o "efeito" e a "presença" manifestam, pois, respectivamente, a "ação" e a "eficiência" do emissor.

Essas determinações da profundidade do campo de presença no qual se institui a interação afetiva de compaixão e de piedade conferem e explicam, mais uma vez, a questão da competência passional assentada no "sentir com" (emoção intensa, tônica, que gera a unidade, a fusão) por parte do compassivo, e no "sentir por" (emoção distribuída e, por isso, átona, marcando a não-conjunção, o interesse) para o piedoso. Os autores citados acrescentam (2001, p. 142):

A realização do sujeito $S$, em face de um mundo $M$ percebido como único e de presença compactada, consagra-o como contraído, unificado, na medida em que não há qualquer distância entre o foco [apreensão local $]^{15}$ e a apreensão [apreensão global], entre a interoceptividade e a proprioceptividade: a apropriação do mundo $\mathrm{M}$ pelo sujeito $\mathrm{S}$ é, de certa maneira, simultânea à sua confrontação.

[...]

A atualização defronta o sujeito $S$ e um mundo $M$ percebido como concentrado e massivo: assim, ela reconstitui em parte

15 Para evitar qualquer confusão com os termos foco e apreensão - visée e saisie, no original em francês, também traduzidos, em outras obras, como: visada e apreensão; focalização e apreensão -, adotados por Fontanille e Zilberberg em Tensão e significação (2001), e que foram completamente reformulados nas obras posteriores de Zilberberg, decidimos optar, sem prejuízo da ideia inicialmente concebida no referido livro, pelos termos apreensão local para foco, e apreensão global para apreensão. 
a tensão entre as duas instâncias S' [sujeito da apreensão local] e S" [sujeito da apreensão global], e permite, se não uma sincronização, pelo menos uma superposição parcial de seus atos e papéis respectivos, de modo que o sujeito poderá ser chamado aqui de mobilizado [...].

O devir característico ao sentir que instaura o sujeito compassivo configura-se, portanto, pela presença viva, tônica, do objeto-valor da afetividade (o sofredor), em um campo de presença circunscrito que, desfavorecendo os entornos e colocando o acento de sentido no sofrimento vivido, esclarece a ligação mais intensa, a maior tensão na relação interactancial, e, portanto, o impacto superior sobre o sujeito da percepção, fazendo com que o crer-saber o sofrimento do outro, responsável pelo despertar da afetividade, seja um crer-saber-assumido, típico à interação afetiva realizada. Os valores investidos no objeto-valor ao qual a afetividade é direcionada são sentidos, dessa forma, como sendo do próprio sujeito da percepção; daí a assunção a um ponto de vista mais puro, individualizado, próprio aos valores de absoluto.

No caso do piedoso, o devir fruto da presença atualizada do sofrimento ata a tensão interativa ao fracionamento da atividade perceptiva ampliada aos entornos, àquilo que causa o sofrimento, apontando, simultaneamente, para um grau menor de tonicidade perceptiva, porque distribuída na extensão do espaço percebido, e, consequentemente, para o aumento da atuação do inteligível na produção do pesar. Os valores investidos no objeto-valor do compadecimento, misturados àqueles que caracterizam os entornos, o mal causador do padecimento, são, dessa forma, apreendidos como exteriores, reconhecidos pelo sujeito da percepção, mas como pertencentes à situação do sujeito sofredor; o que explica a menor simetria de lugares estabelecida entre eles e a adesão 
a um ponto de vista menos individual, menos próximo aos valores de absoluto e próprios aos valores de universo, mais gerais.

Segundo os autores de Tensão e significação (2001), o modo de existência realizado, na perspectiva da intensidade, é mesmo compacto e, na da extensidade, uno e singular (Esquema 1), o que retrata o estilo contensivo da relação de conjunção entre sujeito apaixonado e objeto da paixão. Já o modo atualizado tem intensidade concentrada, mas extensidade massiva (Esquema 1), resultando em um estilo contensivo, uma não-disjunção interativa.

Esquema 1: Regimes de intensidade e extensidade

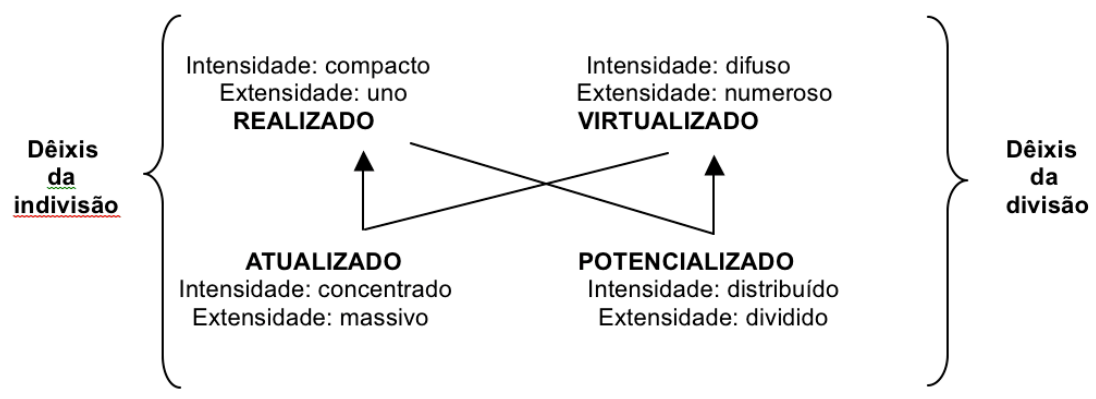

Fonte: FONTANILLE; ZILBERBERG, 2001, p. 136.

Eles assinalam ainda (2001, p. 126): "quando a profundidade se projeta na competência do sujeito da percepção, ela dá lugar à dialética dos 'pontos de vista': aos intervalos inerentes à distância correspondem morfologias perceptivas, ora apenas distintas, ora irredutíveis umas às outras [...]". É, nesse sentido, a modulação tensiva, própria aos estados de alma 
em questão, que, ao sobredeterminar o modo de presença e a circulação dos valores investidos no objeto da afetividade, delineia diferentes modos de o perceber e, consequentemente, de com ele interagir.

A distinção entre o compassivo e o piedoso não está, por conseguinte, necessariamente no grau de intensidade do sentir (manifestado), mas, sobretudo, na variação da tonicidade perceptiva da presença (manifestante) quando da coexistência com o sujeito da percepção. As especificidades sintáxicas dos modos de interação afetiva examinados remetem, pois, a um ponto de vista totalmente localizado por parte do sujeito compassivo, típico à apreensão local $\left(\right.$ foco $^{16}$ ), na qual, conforme explicam Fontanille e Zilberberg (2001, p. 130), "a intensidade e a extensidade perceptivas evoluem de maneira inversa: quanto menos objetos se visam de uma só vez, mais bem estes são visados", e a um outro mais globalizado no caso do piedoso, característico a uma apreensão global, "que procede por delimitação de uma extensão, demarcando o domínio para aí circunscrever o objeto" (FONTANILLE; ZILBERBERG, 2001, p. 130).

No primeiro caso, o efeito de compaixão, associado à operação de triagem axiológica, aos valores de absoluto, firma-se, pois, no tipo perceptivo da apreensão local, ou seja, o máximo de intensidade está vinculado à unicidade do objeto-valor do pesar, a uma grandeza caracterizada pela alta tonicidade perceptiva do valor nela investido e sua consequente exclusividade no campo de presença do sujeito compassivo, com a interação afetiva desencadeada sendo marcada por uma maior homoge-

16 Reiteramos: os termos apreensão local e apreensão global estão sendo usados segundo a definição de foco e apreensão, respectivamente, apresentada em Tensão e significação (2001), e foram adotados para evitar uma confusão com os sentidos que lhes foram atribuídos nas obras posteriores de Claude Zilberberg. 
neidade interactancial. No segundo, por sua vez, o efeito de piedade, atrelado não necessariamente aos valores de absoluto, parece estar relacionado à operação de mistura e totalização axiológica, instituindo-se na apreensão global, mais próxima aos valores de universo. Embora se configure certa intensidade, a extensidade massiva multiplica os valores apreendidos no ato perceptivo, desestabilizando a homogeneidade, a simetria entre os actantes envolvidos.

Assim, se apreender de maneira local é focalizar, selecionar, triar em uma extensão aberta a zona em que se exercerá a percepção mais intensa, renunciando ao número dos elementos apreendidos em prol da saliência perceptivas de alguns, ou de um único (FONTANILLE; ZILBERBERG, 2001), podemos dizer que o estado de alma de compaixão se instaura quando a percepção do sujeito apaixonado recai exclusivamente sobre o sofredor, o objeto-valor do pesar suscitado, ou melhor, sobre a manifestação explícita do padecimento deste último, quando não o desespero vivido e demonstrado por ele, o qual concentraria os valores em jogo e, consequentemente, a tensão, a intensidade que convoca e afeta o sujeito da percepção, justificando a sua maior convocação sensível, a configuração do crer-saber-assumido.

O efeito patêmico de piedade, por outro lado, surgiria a partir de uma apreensão que privilegia não apenas o sofrimento do outro em si, mas também o "mal causador", a situação que faz ser o padecimento, com os valores caracterizados na extensão do domínio espacial do ato perceptivo. Nesse caso, a dor do outro vem para o sujeito da percepção por meio de catálise, como inferência feita a partir do espaço percorrido. A extensão da composição figurativa do objeto-valor do pesar, ao incluir o entorno, com o acento de sentido colocado na situação que causa o sofrimento, comprometeria a apro- 
priação, a assimilação síncrona e o partilhar entre os sujeitos, distendendo também o sentir correspondente à tensão interactancial. Com a atenção voltada aos entornos, e não só ao sujeito que é por ele afetado, o sofrimento é deduzido; daí a sensibilização, o pesar gerado, ter natureza mais inteligível crer-saber-aderido -, com menor convocação estésica.

Essa nossa interpretação é diferente daquela proposta por Fontanille $(2003,2005,2006)$, quando ele assinala, a partir das considerações de Heidegger sobre a "preocupação mútua", a diferença entre compaixão e piedade como sendo da ordem de traços aspecto-temporais. Para o semioticista citado, "a gama passional se diversifica e se define segundo privilegiemos, na existência do outro, o seu devir, a sua situação ou o seu destino" (FONTANILLE, 2005, p. 246 ${ }^{17}$ ). Ele explica (FONTANILLE, 2005, p. 24418):

A compaixão, em suma, pode ser potencial, sem atualização imediata, e funcionar como uma disposição sempre voltada para as situações por vir, tanto quanto para as situações presentes. A piedade, ao contrário, é obrigatoriamente atualizada, e só surge a partir de um acontecimento atestado ou uma situação presente, ou mesmo já instalada anteriormente.

17 Trecho original: "La gamme passionnelle se diversifie et se définit donc, selon que l'on vise dans l'existence d'autrui son devenir, sa situation ou sa destinée."

18 Trecho original: "La compassion, en somme, peut être potentielle, sans actualité immédiate, et fonctionner comme une disposition toujours tendue vers les situations à-venir, tout autant que vers les situations présentes. La pitié, en revanche, est obligatoirement actualisée, et n'apparaît qu'en relation avec un événement attesté ou une situation présente, voire déjà installée antérieurement.

En somme, on peut bien éprouver de la compassion pour tout ce qui attend l'autre dans cette "vallée de larmes" qu'est notre monde, sans pour autant éprouver pour lui de la pitié; si même on éprouvait en ce cas de la pitié, ce serait au prix d'un considérable effort d'actualisation imaginaire de l'à-venir, ou même au nom de quelque fatalisme qui considérerait le non-accompli (dans le monde concret) comme déjà advenu (dans le monde écrit du destin). De la compassion à la pitié, il se produit donc une réduction des situations possibles à une situation-occurence réalisée. La compassion porte sur le "pouvoir être", à la différence de la pitié qui ne peut porter que sur un état actuel." 
Em resumo, podemos experimentar compaixão por tudo aquilo que aguarda o outro nesse "vale de lágrimas" que é o nosso mundo, sem por isso sentir dele piedade; se mesmo assim sentíssemos piedade, seria à custa de um considerável esforço de atualização imaginária do porvir, ou mesmo em nome de algum fatalismo que considerasse o não-consumado (no mundo concreto) como já advindo (no mundo traçado do destino). Da compaixão à piedade, produz-se, então, uma redução das situações possíveis a uma situação-ocorrência realizada. A compaixão recai sobre o "poder ser", diferentemente da piedade que só pode incidir sobre um estado atual.

Se é mais apropriado pensar a diferença entre compaixão e piedade com base na temporalidade das situações em causa, ou no modo de presença do objeto-valor do pesar instaurado no campo de presença que se cria entre os interactantes, com o acento de sentido recaindo, em um dos casos, exclusivamente sobre o sofrimento experimentado, ou, na outra possibilidade, também sobre o "mal causador", apenas o exame de discursos no ou a partir dos quais esses efeitos passionais se configurem poderá avaliar. Sabemos que a hipótese lançada por nós só pode ser confirmada através de uma análise que tenha as interações patêmicas examinadas in praesentia, isto é, manifestadas. De qualquer maneira, parece estar claro que as condições de emergência do sentir do compassivo e do piedoso estariam ligadas, prioritariamente, às diferentes formas pelas quais os valores investem e estruturam o campo de presença do sujeito sensível em uma paixão e outra, apontando para as operações de base perceptiva que aparecem associadas à articulação do sensível com o inteligível, definindo, dessa forma, diferentes estilos de valoração do objeto, tanto no nível figurativo (manifestante) quanto no nível figural (manifestado) dos enunciados. 


\section{Considerações gerais sobre a análise lexical e tensiva}

A partir dos elementos semânticos levantados pela investigação das definições, procuramos compreender, pelo menos de duas maneiras, a configuração subjacente aos estados de alma de compaixão e piedade: (i) no que diz respeito à identidade modal da relação entre os sujeitos compassivo e piedoso, e (ii) naquilo que tange às condições de emergência dos afetos em questão, às modulações tensivas que gerenciam o ato perceptivo e instauram a interação entre os sujeitos evolvidos. A ideia era a de examinar a existência de semelhanças e possíveis diferenças na configuração sintáxica desses efeitos passionais, levantando elementos para defender a distinção entre eles.

Na perspectiva das modalizações existenciais, as modalidades regentes da identidade do compassivo e do piedoso, querer-ser e dever-ser respectivamente, definem, por meio de sua incidência sobre a junção, as especificidades da polêmica contratual que subjaz aos modos de interação afetiva entre o sujeito da percepção e o objeto-valor percebido em um caso e outro, apontando para uma diferença significativa de estruturação do pivô passional (o crer-saber a dor alheia) de ambos os estados de alma, e não só em termos sintáxicos, mas também semânticos.

Enquanto valores modais, o querer e o dever se apresentaram como os elementos regentes das axiologias envolvidas em tais núcleos patêmicos, com a interação compassiva dirigida por um ponto de vista mais individualizado (valores de absoluto), procedente do íntimo humano, próprio a uma sanção passional de caráter endógeno, isto é, fruto da sincre- 
tização actancial dos papéis de destinador e destinatário na figura do compassivo, e a piedosa, por um ponto de vista um pouco mais generalizante (mais próximo aos valores de universo), relacionado aos deveres sociais, morais e religiosos, com uma sanção de ordem exógena, ou seja, advinda da discretização actancial das funções de destinador e destinatário no ator piedoso. Isso explica o efeito de espontaneidade, de origem natural e instintiva do "sentir com" na compaixão, e o efeito de maior racionalidade, de determinação sócio-cultural do "sentir por" na piedade.

Ao se constituir como operadores da modalização da junção (do modo de conjunção, uma vez que ambas são paixões de conjunção), da relação intersubjetiva estabelecida entre os sujeitos envolvidos, ou, mais especificamente, a propósito das funções actanciais, entre o sujeito da percepção e objeto-valor da afetividade, do pesar, querer e dever apontaram para as peculiaridades da configuração do crer-saber, instaurado como assumido, no caso da compaixão, e aderido, no da piedade. Foi então que se evidenciou a necessidade de um exame "aquém" da identidade modal do compassivo e do piedoso, voltada às condições de emergência das interações examinadas. Afinal, conforme destacam Fontanille e Zilberberg (2001, p. 309), "os dispositivos em questão não são pois sequências que acumulam apenas conteúdos modais (enfim, 'sequências' modais), mas configurações cuja sintaxe interna é assegurada pelo jogo das correlações tensivas".

As diferenças qualitativas do pivô passional, o crer-saber que fundamenta o compadecimento sentido ante o sofrimento de outrem, bem como do modo de conjunção, mostraram poder ser, de fato, produto da maneira pela qual o objeto da afetividade suscitada é apreendido na atividade perceptiva, exercida em um espaço tensivo de coexistência no qual a 
inserção dos valores se faz de forma diversificada, provocando modos de interação afetiva distintos.

Na compaixão, a inter-relação (patêmica) se estabeleceria em um campo de presença de profundidade mínima, colocando o acento de sentido diretamente no objeto da afetividade; o que abrevia o processo interpretativo subjacente ao crer-saber a dor do outro, acelerando a inserção dos valores a ele relacionados. Isso explica a maior convocação sensível do sujeito da percepção e a menor possibilidade de assimilação inteligível da presença, tal como é típico a um estado de alma da ordem da fusão.

Na piedade, ao contrário, nossa hipótese é a de que é maior a distância entre o centro da atividade perceptiva e o objeto-valor do pesar, concentrando a intensidade em uma extensão mais ampla, na qual se inclui o entorno, a situação, que caracteriza o sofrimento. Essa expansão do campo de atuação da sanção desacelera a emergência dos valores investidos no objeto, diminuindo a sua força de impacto e com ela a convocação sensível, o que permite um processamento mais inteligível da presença com a qual a interação afetiva se estabelece, tal como se verifica nos estados de alma instituídos por uma aproximação e não exatamente uma interação fusional.

Logo, embora haja nos dois casos uma sensibilização operada pela intensidade da situação disfórica vivida, é distinta a maneira pela qual ela se imprime na presença: fechando os horizontes do campo de interação, o que recrudesce a sua força de impacto, o seu poder de convocação sensível; ou abrindo-o, e, então, restabelecendo a atuação da assimilação inteligível. Há, dessa forma, comoção tanto na compaixão quanto na piedade; varia, no entanto, o seu grau de atuação na configuração do "valor do valor", da sanção intersubjetiva formulada pelo sujeito da percepção. 
Parece ser, com efeito, e como demonstrou essa análise lexical realizada, o modo de perceber o objeto da afetividade, ou, mais especificamente, o modo de apreensão dos valores nele inscritos, o responsável tanto pelas condições de produção do "valor do valor", isto é, do valor subjetivo dado ao valor objetivo manifestado, quanto, por conseguinte, das características típicas a determinado modo de interagir, de se relacionar (afetivamente) com o que representa o outro. De toda forma, sabemos que é preciso ainda verificar como essa sintaxe subjacente aos efeitos de compaixão e piedade se comporta no discurso em ato, na "interação viva" com uma presença específica, porque discursivizada, inserida no campo perceptivo do sujeito da percepção que virá a ser compassivo ou piedoso.

\section{Referências}

BARROS, D. L. P. Teoria do discurso. Fundamentos semióticos. São Paulo: Humanitas, 2001.

DISCINI, N. Um algoritmo da percepção: o sujeito do afeto. In: MARCHEZAN, R. C.; CORTINA, A.; BAQUIÃO, R. C. (Orgs.) A abordagem dos afetos na semiótica. São Carlos: Pedro \& João editores, 2011. p. 149-172.

FONTANILLE, J. La participation sensible. Sémiotique de la pitié. In: OUELLET, P. (Org.) Le soi et l'autre. L'énonciation de l'identité dans les contextes interculturels. Canadá: Les Presses de l'Université Laval, 2003. p. 217-237. 
FONTANILLE, J. Pitié. In: RALLO-DITCHE, E.; FONTANILLE, J.; LOMBARDO, P. Dictionnaire des passions littéraires. Paris: Belin, 2005. p. 240-265.

FONTANILLE, J. Le temps de la compassion. La diffusion thymique et ses régimes temporels. In: HÉBERT, L. (Org.) Le plaisir des sens. Euphories et dysphories des signes. Canadá: PUL, 2006. p. 23-51.

FONTANILLE, J.; ZILBERBERG, C. Tensão e significação. Trad. Ivã Carlos Lopes, Luiz Tatit e Waldir Beividas. São Paulo: Humanitas, 2001.

GREIMAS, A. J. Du sens II. Paris: Seuil, 1983.

GREIMAS, A. J. De la nostalgie. Etude de sémantique lexicale. In: HÉNAULT, A. (Org.) Questions des sémiotiques. Paris: PUF, 2002. p. 593-600.

GREIMAS, A. J.; FONTANILlE, J. Semiótica das paixões. Dos estados de coisas aos estados de alma. Trad. Maria José Rodrigues Coracini. São Paulo: Ática, 1993.

LOPES, I. C. A noção de "Profundidade" na semiótica. CASA, vol. 4, no 2, 2006. Disponível em: <http://seer.fclar.unesp.br/ casa/article/view/564/485>. Acesso em: 23 jan. 2016.

RICOT, J. Du bon usage de la compassion. Paris: PUF, 2013.

ROUSSEAU, J. J. Emílio ou da educação. Trad. Roberto Leal Ferreira. São Paulo: Martins Fontes, 2004. 
SMITH, A. Théorie des sentiments moraux. Trad. Michaël Biziou, Claude Gautier e Jean-François Pradeau. Paris: PUF, 1999.

Artigo recebido em fevereiro de 2016 e aprovado em abril de 2016.

\section{Como citar este trabalho:}

LIMA, Eliane Soares de. Compaixão e piedade: diferentes modos de interação afetiva. CASA: Cadernos de Semiótica Aplicada, São Paulo, v. 14, n. 01, p. 83-127, julho, 2016. Disponível em: <http://seer.fclar.unesp.br/casa>. Acesso em "dia/mês/ano". http://dx.doi.org/10.21709/casa. v14i1.8372. 